DOI: $10.19195 / 0137-1134.112 .2$

\title{
JAROSŁAW CIESIELSKI
}

Uniwersytet Wrocławski

\section{REJESTRY PRZEDSIĘBIORCÓW A OCHRONA DANYCH OSOBOWYCH}

\begin{abstract}
Abstrakt: W zakresie ochrony danych osobowych przedsiębiorców prawodawstwo polskie obecnie przewiduje dwa różne rozwiązania. Pierwsze z nich obejmuje dane osób fizycznych prowadzących działalność gospodarczą, drugie natomiast dotyczy danych przedsiębiorców będących osobami prawnymi albo jednostkami organizacyjnymi nieposiadającymi osobowości prawnej, którym ustawodawca przyznaje zdolność prawną. Status obu kategorii danych jest zbliżony. Na podstawie reguły art. 39b u.s.d.g. od 19 maja 2016 r. do jawnych danych i informacji udostępnianych przez CEIDG nie stosuje się przepisów ustawy o ochronie danych osobowych, poza art. 14-19a i art. 21-22a oraz rozdziałem 5 tej ustawy. W związku z tym na organie prowadzącym Centralną Ewidencję, jak i podmiotach przetwarzających dane w niej zawarte ciążą jedynie niektóre obowiązki, takie jak m.in. obowiązek zabezpieczenia danych przed ich udostępnieniem osobom nieupoważnionym, zabraniem przez osobę nieuprawnioną, przetwarzaniem z naruszeniem ustawy oraz zmianą, utratą, uszkodzeniem lub zniszczeniem; nie jest jednak konieczne spełnienie obowiązków informacyjnych i przesłanek przetwarzania danych. Żadne z przepisów u.o.d.o. nie mają zastosowania względem danych osób prawnych, jednostek nieposiadających osobowości prawnej, którym ustawa przyznaje zdolność prawną (w tym osobowych spółek handlowych) i innych podmiotów niebędących osobami fizycznymi. Dane ujawnione w KRS nie podlegają ochronie ustawy, gdy nie dotyczą osób fizycznych. Względem danych osobowych wspólników spółki, członków organów czy też danych osób fizycznych wpisanych na listę dłużników niewypłacalnych reguły u.o.d.o. znajdują zastosowanie, gdy są wykorzystywane w celu innym, aniżeli ich identyfikacja jako pełniących wskazane funkcje bądź jako osób figurujących w rejestrze dłużników niewypłacalnych.
\end{abstract}

Słowa kluczowe: ochrona danych osobowych, KRS, CEIDG, rejestry przedsiębiorców

Ochrona danych osobowych przedsiębiorców stanowi istotne zagadnienie zarówno z punktu widzenia samych osób funkcjonujących w obrocie jedno- i dwustronnie profesjonalnym, jak i z perspektywy podmiotów chcących przetwarzać informacje ich dotyczące. Nałożone na przedsiębiorców obowiązki rejestracyjne, a także jawność danych ujawnianych w Centralnej Ewidencji i Informacji o Działalności Gospodarczej ${ }^{1}$ oraz Krajowym Rejestrze Sądowym ${ }^{2}$ z jednej stro-

${ }^{1}$ Dalej także „CEIDG”, „Centralna Ewidencja”.

2 Dalej również „KRS”, „Rejestr”. 
ny ułatwiają obrót i zwiększają jego pewność, z drugiej implikują wiele pytań o granice możliwej ich eksploatacji. Wyraźne przedstawienie odrębności w zakresie ochrony danych osobowych przedsiębiorców pozostaje istotne w kontekście opracowywanych zmian związanych z przygotowywaną nową ustawą o ochronie danych osobowych ${ }^{3}$, dostosowujących przepisy krajowe do uregulowań prawodawstwa unijnego ${ }^{4}$. Aktualnie rodzimy ustawodawca przewiduje bowiem dwa modele ochrony: pierwszy z nich obejmuje dane osób fizycznych prowadzących działalność gospodarczą, drugi natomiast dotyczy danych przedsiębiorców będących osobami prawnymi albo jednostkami organizacyjnymi nieposiadającymi osobowości prawnej, którym ustawodawca przyznaje zdolność prawną.

\section{OCHRONA DANYCH OSOBOWYCH A WPISY DANYCH DO CEIDG}

Zgodnie z art. 14 ust. 1 ustawy z dnia 2 lipca 2004 r. o swobodzie działalności gospodarczej ${ }^{5}$ możliwość rozpoczęcia prowadzenia działalności gospodarczej warunkuje złożenie przez przedsiębiorcę będącego osobą fizyczną wniosku o wpis do Centralnej Ewidencji i Informacji o Działalności Gospodarczej, natomiast w wypadku przedsiębiorcy podlegającego rejestracji w Krajowym Rejestrze Sądowym niezbędne pozostaje dokonanie przez sąd rejestrowy wpisu danego podmiotu do rejestru przedsiębiorców, względnie powstanie spółki kapitałowej w organizacji (zawiązanie spółki - podpisanie umowy sp. z.o.o.; przyjęcie i podpisanie statutu S.A. oraz objęcie wszystkich akcji tej spółki) ${ }^{6}$. Tym samym warunkiem formalnym prowadzenia działalności gospodarczej przez osobę fizyczną jest uzyskanie wpisu do funkcjonującej od dnia 1 lipca 2011 r. CEIDG, prowadzonej w systemie teleinformatycznym przez ministra właściwego do spraw gospodarki ${ }^{7}$. Przedsiębiorcy prowadzący działalność gospodarczą jako osoby prawne (m.in. kapitałowe spółki handlowe), jak i handlowe spółki osobowe, podlegają obowiązkowi uzy-

${ }_{3}$ Projekt z dnia 8 lutego 2018 r. dostępny pod adresem: https://www.gov.pl/cyfryzacja/projekt -ustawy-o-ochronie-danych-osobowych-skierowany-na-komitet-do-spraw-europejskich-rady-ministrow (dostęp: 20.05.2018).

4 Wchodzące w życie w dniu 25 maja 2018 r. Rozporządzenie Parlamentu Europejskiego i Rady (UE) 2016/679 z dnia 27 kwietnia 2016 r. w sprawie ochrony osób fizycznych w związku z przetwarzaniem danych osobowych i w sprawie swobodnego przepływu takich danych oraz uchylenia dyrektywy 95/46/WE (ogólne rozporządzenie o ochronie danych), Dz. UE L 119 z 4 maja 2016 r. Akt ten tak, jak i inne unijne rozporządzenia, będzie znajdował bezpośrednie zastosowanie w polskim porządku prawnym.

5 Tekst jedn. Dz.U. z 2017 r. poz. 2168 z późn. zm., dalej „u.s.d.g.”.

6 Art. 14 ust. 1 u.s.d.g w zw. z art. 310 § 1 k.s.h. oraz w zw. z art. $161 \S 1$ k.s.h.

7 Regulowana art. 23-39 u.s.d.g. Do ich wejścia w życie zastosowanie znajdowały zasady prowadzenia ewidencji działalności gospodarczej regulowane art. 7a-7i ustawy z dnia 19 listopada 1999 r. Prawo działalności gospodarczej, Dz.U. z 1999 r. Nr 101, poz. 1178 z późn. zm., dalej jako „u.p.d.g.”. 
skania wpisu do funkcjonującego od dnia 1 stycznia 2001 r. rejestru przedsiębiorców Krajowego Rejestru Sądowego ${ }^{8}$.

Odnosząc się w pierwszej kolejności do osób fizycznych prowadzących jednoosobowo działalność gospodarczą, zauważyć należy, że wedle treści art. 25 u.s.d.g. wpisowi do CEIDG podlega wiele danych, które następnie są udostępniane, $\mathrm{z}$ wyjątkiem numeru PESEL, daty urodzenia oraz danych kontaktowych przedsiębiorcy w przypadku, gdy podając je, osoba uprawniona sprzeciwiła się ich udostępnianiu w Centralnej Ewidencji (art. 37 ust.1 pkt 1 u.s.d.g.). Dane nieobjęte wyłączeniem pozostają jawne i są udostępniane przez CEIDG na prowadzonej przez nią stronie internetowej ${ }^{9}$. Wiele danych podlegających wedle art. 25 ust. 1 wpisowi do Centralnej Ewidencji, a dotyczących każdorazowo osób fizycznych, należałoby uznać za dane osobowe w myśl art. 6 ustawy o ochronie danych osobowych ${ }^{10}$. Przepis ten kwalifikuje do nich wszelkie informacje dotyczące zidentyfikowanej lub możliwej do zidentyfikowania osoby fizycznej, to jest takiej, której tożsamość można określić bezpośrednio lub pośrednio, w szczególności przez powołanie się na numer identyfikacyjny albo jeden lub kilka specyficznych czynników określających jej cechy fizyczne, fizjologiczne, umysłowe, ekonomiczne, kulturowe lub społeczne, nie uważając informacji za umożliwiającą określenie tożsamości osoby, jeżeli wymagałoby to nadmiernych kosztów, czasu lub działań ${ }^{11}$. W doktrynie wskazuje się, że pod zwrotem, ,wszelkie informacje” $\mathrm{z}$ art. 6 u.o.d.o. należy rozumieć informacje dotyczące każdego aspektu funkcjonowania osoby fizycznej, jej stosunków osobistych i majątkowych, życia zawodowego, prywatnego, wykształcenia, cech charakteru ${ }^{12}$. Do oceny, czy ustalenie tożsamości pociąga za sobą nadmierne koszty, czas lub działania, niezbędne jest uwzględnienie możliwości technicznych w czasie przetwarzania danych ${ }^{13}$.

Wśród danych podlegających wpisowi do CEIDG za dane kwalifikowane jako dane osobowe w ujęciu u.o.d.o. należałoby uznać nie tylko numery identyfikacyjne (PESEL, NIP) przedsiębiorcy, ale także takie elementy pozwalające

8 Tj. od chwili wejścia w życie ustawy z dnia 20 sierpnia 1997 r. o Krajowym Rejestrze Sądowym (tekst jedn. Dz.U. z 2017 r. poz. 700 z późn. zm.) zwanej dalej „u.k.r.s.”. Rejestr ten zastąpił mający swoje źródła w prawie międzywojennym rejestr handlowy, wprowadzony do polskiego systemu prawnego dekretem Naczelnika Państwa z dnia 7 lutego 1919 r. o rejestrze handlowym, Dziennik Praw Państwa Polskiego nr 14 poz. 164.

9 Art. 37 ust. 1 pkt 1 w zw. z art. 38.ust. 1 i 2 u.s.d.g.

${ }^{10}$ Ustawa z dnia 29 sierpnia 1997 r. o ochronie danych osobowych, tekst jedn. Dz.U. z 2016 r. poz. 922 z późn. zm., dalej ,u.o.d.o.”.

11 Okoliczność stosowania omawianej ustawy do osób fizycznych należy wywodzić również z jej art. 2 ust. 1, zastrzegającego, że ustawa określa zasady przetwarzania danych osobowych oraz prawa osób fizycznych w tym zakresie, nieodnoszącego się do praw innych podmiotów prawa.

12 J. Barta, P. Fajgielski, R. Markiewicz, Ochrona danych osobowych. Komentarz, Warszawa 2015, s. 304.

13 A. Drozd, Ustawa o ochronie danych osobowych. Komentarz. Wzory pism i przepisy, Warszawa 2006, s. 51. 
na jego identyfikację, jak np. adres poczty elektronicznej i dane adresowe (o ile pozostają zbieżne z danymi osoby fizycznej prowadzącej działalność gospodarczą) oraz datę jego urodzenia. W piśmiennictwie istnieje jednak rozbieżność, czy dane o osobach fizycznych prowadzących działalność gospodarczą (w tym także o wspólnikach spółek cywilnych) należy kwalifikować jako dane osobowe w ujęciu u.o.d.o. ${ }^{14}$ Zważając na literalne brzmienie art. 6 ust. 1 u.o.d.o., termin „dane osobowe” należy uznać za dotyczący wyłącznie osób fizycznych, a więc nieznajdujący zastosowania do innych podmiotów prawa, takich jak np. osoby prawne i jednostki organizacyjne nieposiadające osobowości prawnej (np. osobowe spółki handlowe). Po wejściu w życie u.o.d.o. niektórzy autorzy podkreślali, że dane, choćby znajdowały się w zbiorach ogólnodostępnych, o ile tylko pozwalają na identyfikację konkretnych osób, nie zostały wyłączone spod ochrony ustawy. Są one bowiem zbliżone do danych kontaktowych do pracowników zajmujących określone stanowisko (takich jak np. prowadzona przez wydawnictwo lista numerów telefonu do księgowych poszczególnych spółek).W konsekwencji podnoszono, że dane te stanowią informację drugorzędną względem informacji identyfikujących przedsiębiorcę i kontakt do niego i o ile pozwalają one na identyfikację danej osoby — bez względu na cel lub funkcję, jaką spełniają — podlegają ochronie $^{15}$.

Odmienne stanowisko zajął Naczelny Sąd Administracyjny w wyroku z dnia 28 listopada 2002 r. ${ }^{16}$, wydanym w sprawie zapoczątkowanej przez nieuwzględnienie przez Generalnego Inspektora Ochrony Danych Osobowych ${ }^{17}$ skargi przedsiębiorcy (adwokata) na operatora telefonii komórkowej. Przedsiębiorca ten wniósł o wszczęcie przez Inspektora postępowania i wydanie decyzji nakazującej zaprzestania przetwarzania jego danych do celów marketingowych oraz wysyłania telefonicznych wiadomości tekstowych zawierających reklamy ${ }^{18}$. W swym rozstrzygnięciu NSA zważył, że ochrona danych osobowych, czyli informacji za-

14 Tak m.in. G. Sibiga, Postępowanie w sprawach ochrony danych osobowych, Warszawa 2003, s. 33.; J. Barta, P. Fajgielski, R. Markiewicz, op. cit., s. 305 i literatura tam przywołana.

15 A. Mednis, Ustawa o ochronie danych osobowych. Komentarz, Warszawa 1999, s. 25-26.

16 Dotyczący przetwarzania w celach marketingowych informacji o charakterze osobowym osób prowadzących działalność gospodarczą wyrok NSA z dnia 28 listopada 2002 r., II S.A. 3389/01, publ. Centralna Baza Orzeczeń Sądów Administracyjnych, http://orzeczenia.nsa.gov.pl/doc/C02DDC2452 (dostęp: 20.05.2018).

17 Dalej także jako „GIODO”, „Generalny Inspektor”.

$18 \mathrm{~W}$ toku postępowania ustalono, że umowa o świadczenie usług telekomunikacyjnych została zawarta z kancelarią adwokacką skarżącego, który korzystał z przedmiotowego telefonu zarówno w pracy zawodowej, jak i prowadząc rozmowy prywatne, a przetworzone przez operatora dane pochodziły z informacji udostępnionych w publicznych rejestrach. GIODO, opierając się o wyrok SN z dnia 14 lipca 1999 r. (II CKN 351/98, OSNC 2000, Nr 2, poz. 36), stwierdził, że chociaż adwokat nie jest przedsiębiorcą, to prowadzona przez niego działalność ma charakter gospodarczy, podlegając ustawie Prawo o adwokaturze. W związku z tym Generalny Inspektor wydał w sprawie decyzję odmowną wskazując, że ochrona wynikająca z ustawy wyłączona została wobec każdego podmiotu, którego aktywność nosi cechę działalności gospodarczej. 
równo identyfikujących, jak i osobopoznawczych dotyczących osoby fizycznej, zidentyfikowanej lub możliwej do zidentyfikowania, odnosi się zgodnie z art. 2 u.o.d.o. jedynie do osób fizycznych, których dane osobowe są lub mogą być przetwarzane w zbiorach danych, a prawo do ochrony tych danych stanowi emanację praw osobistych człowieka, mając przede wszystkim zapewnić poszanowanie prywatności, godności czy osobowości człowieka ${ }^{19}$. Ochrona ta nie odnosi się natomiast do danych indywidualnych dających się powiązać z podmiotem gospodarczym albo inną osobą prawną lub jednostką organizacyjną nieposiadającą osobowości prawnej, pomimo że informacje te wspólnie z danymi osobowymi tworzą wspólną kategorię danych jednostkowych ${ }^{20}$. W tym zakresie NSA odwołał się do dominującego w krajach Unii Europejskiej (występującego m.in. w Belgii, Finlandii, Francji, Grecji, Irlandii, Holandii, Portugalii, Hiszpanii, Niemczech, Szwecji, Wielkiej Brytanii) stanowiska, w myśl którego ochrona danych osobowych obejmuje jedynie informacje dotyczące osób fizycznych ${ }^{21}$. Podkreślono przy tym, że w niektórych krajach wprowadza się dodatkową ochronę osób prawnych, przy czym ma ona charakter słabszy i zróżnicowany. Sąd ten również zaakcentował, że dyrektywa 95/46/EC 22 , której postanowienia zostały implementowane do polskiego porządku prawnego postanowieniami u.o.d.o., wyłączała spod swego zastosowania ustawodawstwo przewidujące ochronę osób prawnych w związku z przetwarzaniem danych ich dotyczących ${ }^{23}$. Jednocześnie NSA wskazał, że nazwa kancelarii oraz numer jej telefonu służą do identyfikacji jednostki organizacyjnej, a nie osoby fizycznej, podobnie jak nazwa spółki cywilnej, nie wchodząc w zakres

19 J. Barta, R. Markiewicz, Ochrona danych osobowych. Komentarz, Zakamycze 2001, s. 163.

20 W ocenie Sądu przemawia za tym rozróżnienie zawarte w ustawie z dnia 29 czerwca $1995 \mathrm{r}$. o statystyce publicznej (tekst jedn. Dz.U. z 2016 r. poz. 1068 z późn. zm.). Należy uznać, iż NSA miał na uwadze treść art. 42 ustawy, wedle którego krajowy rejestr urzędowy podmiotów gospodarki narodowej obejmuje trzy grupy podmiotów: osoby prawne, jednostki organizacyjne niemające osobowości prawnej, osoby fizyczne prowadzące działalność gospodarczą. Zob. też. G. Szpor, Publicznoprawna ochrona danych osobowych, „Przegląd Ustawodawstwa Gospodarczego” 1999, nr 12, s. 6.

21 J. Barta, R. Markiewicz, op. cit., s. 164.

22 Dyrektywa 95/46/WE Parlamentu Europejskiego i Rady z dnia 24 października 1995 r. w sprawie ochrony osób fizycznych w zakresie przetwarzania danych osobowych i swobodnego przepływu tych danych, Dz.U. L 281 z dnia 23 listopada 1995 r. Została ona uchylona Rozporządzeniem Parlamentu Europejskiego i Rady (UE) 2016/679... Ten akt prawny ujednolica zasady ochrony danych osobowych w Unii Europejskiej, dotychczas harmonizowane postanowieniami dyrektywy. W zakresie niektórych dziedzin państwa członkowskie na podstawie zastrzeżeń traktatowych bądź uprawnień wynikających z innych rozporządzeń zagwarantowały sobie autonomię regulacji, np. odnośnie do obowiązku notyfikacji utworzonych zbiorów danych i ich przetwarzania. Zob. W.R. Wiewiórkowski, Nowoczesne ramy ochrony danych osobowych w Unii Europejskiej, „Monitor Prawniczy" 2012, nr 7 (dod. specj.), s. 3.

23 Punkt 24 Dyrektywy. Podobnie rzecz ma się z odnoszącą się do ochrony osób fizycznych Konwencją 108 Rady Europy z dnia 28 stycznia 1981 r., dotyczącą ochrony osób w związku z automatycznym przetwarzaniem danych osobowych, Dz.U. z 2003 r. Nr 3, poz. 25. 
danych osobowych ${ }^{24}$. Dane te podlegają ogólnej ochronie dóbr osobistych, a nie ochronie wskazanej w u.o.d.o., stanowiącej przejaw działań ustawodawcy zmierzających do zagwarantowania większej ochrony osobom fizycznym. Ochrona jednostek organizacyjnych i osób prawnych, zwłaszcza prowadzących działalność gospodarczą, dotyczy jedynie niektórych fragmentów ich działalności, np. tajemnicy przedsiębiorcy. W ocenie NSA osoba fizyczna decydująca się podjąć przedmiotową działalność godzi się na ograniczenie swojego prawa do prywatności. W piśmiennictwie dominowało stanowisko odmawiające objęcia ochroną u.o.d.o. danych związanych z występowaniem osoby fizycznej w obrocie gospodarczym w roli przedsiębiorcy ${ }^{25}$.

Stan prawny dotyczący ochrony danych osobowych osób fizycznych prowadzących działalność gospodarczą uległ zmianie z dniem 1 stycznia 2004 r., tj. z chwilą wejścia w życie art. 7a ust. 2 u.p.d.g. ${ }^{26}$ Zgodnie z jego brzmieniem CEIDG, tj. prowadzona przez samorządy gminne ewidencja działalności gospodarczej, pozostawała jawna i dane osobowe w niej zawarte nie podlegały przepisom u.o.d.o. Generalny Inspektor Ochrony Danych Osobowych w decyzji z dnia 1 września 2005 r. $^{27}$ stwierdził, że osoba prowadząca działalność gospodarczą musi liczyć się z tym, że jej dane umieszczone w publicznie dostępnych spisach podlegają ograniczonej ochronie, zakresem przedmiotowym u.o.d.o. bowiem objęte są wyłącznie dane osób fizycznych. Ustawa nie znajdowała natomiast zastosowania do przetwarzania informacji o innych podmiotach, zwłaszcza o osobach prawnych, jednostkach organizacyjnych nieposiadających osobowości prawnej oraz co szczególnie istotne - podmiotach prowadzących działalność gospodarczą w oparciu o przepisy u.s.d.g. w takim zakresie, w jakim identyfikowały podmiot w obrocie gospodarczym, pozostając w ścisłym związku z prowadzoną przez niego działalnością gospodarczą. W ocenie GIODO osoba (w tym osoba fizyczna) decydująca się na taką działalność godziła się na ograniczenie swego prawa do prywatności w szerszym zakresie niż inna osoba fizyczna. Naczelny Sąd Administracyjny w wyroku z dnia 15 marca 2010 r. podkreślił jednak, że wejście w życie art. 7a ust. 2 u.p.d.g. (obowiązującego na mocy przepisów wprowadzających u.s.d.g. do końca 2011 r.) nie oznaczało jednak, że u.o.d.o. nie znajdowała w ogóle zastosowania do osób fizycznych prowadzących działalność gospodarcząa ${ }^{28}$. W orzeczeniu tym wskazano, że

${ }^{24}$ Cyt. za: M. Zielińska, Nazwa spółki cywilnej jako dobro osobiste, „Prawo Spółek” 1998, nr 11, s. 7.

${ }^{25}$ X. Konarski, Komentarz do ustawy o świadczeniu usług droga elektroniczna, Warszawa 2004, s. 163.

26 Przepis ten wprowadzono mocą ustawy z dnia 14 listopada 2003 r. o zmianie ustawy Prawo działalności gospodarczej oraz niektórych innych ustaw, Dz.U. Nr 217, poz. 2125.

27 Decyzja GIODO nr GI - DEC - DS - 279/05 z dnia 1 września 2005 r. dotycząca wykorzystania przez bank i agencję (spółkę cywilną), do celów marketingowych, informacji o skarżącym pozyskanych z ogólnodostępnej strony internetowej www.panoramafirm.com.pl oraz Polskich Książek Telefonicznych z dnia 1 września 2005 r., https://giodo.gov.pl/pl/283/1508 (dostęp: 20.05.2018).

28 Wyrok NSA z dnia 15 marca 2010 r., I OSK 756/09, Lex nr 590310. 
przepis ów, stanowiąc wyjątek od reguły ogólnej, nie mógł podlegać interpretacji rozszerzającej, traktując jedynie o wyłączeniu ochrony u.o.d.o. względem danych ujawnionych w ewidencji działalności gospodarczej, a nie wszystkich informacji dotyczących osoby fizycznej prowadzącej działalność gospodarczą. Podniesiono, że konieczność dokonywania takiej wykładni potwierdza art. 51 Konstytucji Rzeczypospolitej Polskiej, statuujący konstytucyjne prawo do ochrony danych osobowych. W ocenie NSA osoba fizyczna prowadząca działalność gospodarczą miała prawo do uzyskania informacji, jakie jej dane są przetwarzane przez podmiot prowadzący ewidencję, a więc do skorzystania z instrumentów wprowadzonych przez u.o.d.o. Wyłączenie z art. 7a ust. 2 u.p.d.g. odnosić przy tym należało tylko do danych o osobie prowadzącej działalność gospodarczą, aktualnie wpisanej do ewidencji działalności gospodarczej. W doktrynie, w tym jeszcze w okresie przed wejściem w życie art. 7a ust. 2 u.p.d.g., wskazywano na niesłuszność odmawiania danym osobowym, dotyczącym osób fizycznych prowadzących różnego rodzaju działalność usługową, społeczną czy zawodową, ochrony właściwej podmiotom nieprowadzącym takiej działalności. Podnoszono, że danych tych nie można kwalifikować jako danych o jednostce funkcjonującej w obrocie, a nie informacji o konkretnej osobie fizycznej, akcentując, że dane dotyczące firmy osoby fizycznej oraz pozostałe dane o osobie (dane o sferze życia prywatnego, rodzinnego itp.) stanowią dane o funkcjonowaniu tej samej jednostki — osoby fizycznej29. Postulowano, by ograniczenie ochrony danych osobowych przedsiębiorcy prowadzącego jednoosobowo działalność gospodarczą jako osoba fizyczna dotyczyło wyłącznie tych danych, których ujawnienie jest konieczne do udziału w obrocie, a ich wykorzystywanie w pozostałym zakresie (poza nim) powinno podlegać u.o.d.o. ${ }^{30}$ Ustawę tą należało stosować do osób fizycznych (,ustawa określa zasady postępowania przy przetwarzaniu danych osobowych oraz prawa osób fizycznych, których dane osobowe są lub mogą być przetwarzane w zbiorach danych" - art. 2 ust 1 u.o.d.o.), a ochronie jako dane osobowe podlegała każda informacja o każdej osobie fizycznej (,za dane osobowe uważa się wszelkie informacje dotyczące zidentyfikowanej lub możliwej do zidentyfikowania osoby fizycznej" - art. 6. ust 1 u.o.d.o.) $)^{31}$. W doktrynie występował pogląd zawężający wyłączenie $\mathrm{z}$ art. 7a ust. 2 u.p.d.g. do danych zawartych w ewidencji, w myśl którego umieszczenie tych danych $w$ innym zbiorze implikowało stosowanie do tego zbioru i jego administratora przepisów u.o.d.o. ${ }^{32}$ Był on nietrafny. Ustawodawca

29 M. Jackowski, Glosa do wyroku z 28.XI.2002 r., II S.A. 3389/01, „Państwo i Prawo” 2004, nr 10, s. 126-131.

30 A. Mednis, Ustawa o ochronie danych osobowych $w$ orzecznictwie sadowym - konsekwencje dla praktyki gospodarczej, [w:] Ochrona danych osobowych. Aktualne problemy i nowe wyzwania, red. G. Sibiga, X. Konarski, Warszawa 2007, s. 228.

31 Przepisy te zachowały przywołane brzmienie.

32 A. Drozd, Ustawa o ochronie danych osobowych. Komentarz. Wzory pism i przepisy, Warszawa 2007, s. 46. 
w art. 7a ust. 2 u.p.d.g. wyłączył stosowanie u.o.d.o. względem danych ujawnionych w ewidencji, a nie wskazał, że wyłącza je względem jednostkowego zbioru danych - ewidencji działalności gospodarczej.

Stan prawny uległ kolejnej zmianie z dniem 1 stycznia 2012 r., tj. z chwilą utraty mocy u.p.g.d. i wejścia w życie u.s.d.g., w brzmieniu nieprzewidującym odpowiednika 7a ust. 2 u.p.d.g. Od tego momentu ochronie wskazanej w u.o.d.o. podlegały także dane osób fizycznych niezależnie od faktu prowadzenia bądź nieprowadzenia przez nie działalności gospodarczej. Tym samym na podmiocie zarządzającym i administrującym danymi identyfikującymi osoby fizyczne prowadzące działalność gospodarczą bądź też pozwalającymi na ich identyfikację ciążył nakaz wypełnienia obowiązków wskazanych w u.o.d.o. - m.in. imperatyw zgłoszenia zbioru danych do rejestracji GIODO ${ }^{33}$. Istniejący wówczas stan prawny w pełni odpowiadał stanowisku przedstawicieli doktryny, wedle których reguły wykładni funkcjonalnej oraz analiza dyrektywy 95/46/EC (wsparta zasadą prounijnej wykładni przepisów krajowych) prowadziły do konstatacji, iż intencją prawodawcy pozostawało nadanie ochronie danych jak najszerszego zakresu podmiotowego ${ }^{34}$.

W ostatnim czasie doszło do ponownej zmiany przepisów i mocą art. 39b u.s.d.g. od 19 maja 2016 r. do jawnych danych i informacji udostępnianych przez CEIDG nie stosuje się przepisów u.o.d.o., z wyjątkiem art. 14-19a i art. 21-22a oraz rozdziału 5 tej ustawy ${ }^{35}$. Jest ona zatem stosowana względem przedmiotowych danych w ograniczonym zakresie. Zważając na stosowanie rozdziału 5 u.o.d.o., należy podkreślić, że na administratorze, który przetwarza dane podlegające ujawnieniu w CEIDG, ciąży wiele obowiązków. W szczególności winien zabezpieczyć dane przed ich udostępnieniem osobom nieupoważnionym, zabraniem przez osobę nieuprawnioną, przetwarzaniem z naruszeniem ustawy oraz zmianą, utratą, uszkodzeniem lub zniszczeniem, nadto powinien prowadzić dokumentację opisującą sposób przetwarzania tych danych. Może on realizować swoje obowiązki przy pomocy powołanego przez siebie administratora bezpieczeństwa informacji. Administrator bezpieczeństwa informacji, a w razie braku jego powołania administrator danych, może dopuścić do przetwarzania wyłącznie upoważnione

$33 \mathrm{~W}$ dalszym ciągu art. 43 ust. 1 pkt 9 u.o.d.o. zawierał wskazanie, że spod obowiązku rejestracyjnego wyłączone były rejestry powszechnie dostępne, a o jawności i powszechnym dostępie do ewidencji od 1 lipca 2011 r. stanowił art. 38 u.s.d.g., niemniej Minister Gospodarki spełnił przedmiotowy obowiązek w dniu 14 lipca 2011 r., a Centralna Ewidencja i Informacja o Działalności Gospodarczej została zarejestrowana pod nr 007771/2011 w księdze nr 100742 ogólnokrajowego rejestru zbiorów danych osobowych GIODO, https://egiodo.giodo.gov.pl/form_ver4.dhtml?form id $=88928649$ (dostęp: 20.05 .2018 ).

${ }^{34}$ Stanowisko takie prezentował M. Jackowski, op. cit. jeszcze przed wejściem w życie art. 7a ust. 2 u.p.d.g., a więc w stanie prawnym, w którym nie wyłączono danych wpisanych do CEIDG spod ochrony u.o.d.o.

35 Przepis wprowadzony art. 1 pkt 21 ustawy z dnia 25 września 2015 r. o zmianie ustawy o swobodzie działalności gospodarczej oraz niektórych innych ustaw, Dz.U. poz. 1893. 
przez siebie osoby podlegające wpisowi do prowadzonej przez niego ewidencji tychże podmiotów. Winien on także zapewnić kontrolę nad tym, jakie dane osobowe, kiedy i przez kogo zostały do zbioru wprowadzone oraz komu są przekazywane. $\mathrm{Z}$ uwagi na jedynie częściowe objęcie ich ochroną u.o.d.o. w przypadku gromadzenia ujawnionych w CEIDG danych osobowych przedsiębiorców nie jest konieczne spełnienie obowiązków informacyjnych i przesłanek przetwarzania danych ${ }^{36}$. Wyłączony jest zatem obowiązek informowania tych podmiotów m.in. o adresie siedziby i pełnej nazwie administratora danych, celu ich zbierania, odbiorcach lub kategoriach odbiorców danych, prawie dostępu do treści swoich danych oraz ich poprawiania. Ma to miejsce niezależnie od tego, czy dane te są zbierane od osoby, której one dotyczą (obowiązki z art. 24 u.o.d.o.) - np. dane pozyskane $\mathrm{z}$ wystawionej przez przedsiębiorcę faktury i ujawnione równocześnie w CEIDG - czy są zbierane nie od osoby, której one dotyczą, np. pobrane wprost $\mathrm{z}$ bazy CEIDG lub uzyskane od innego podmiotu, a pokrywające się z informacjami wynikającymi z Centralnej Ewidencji (obowiązki z art. 25 u.o.d.o.). Ustawa o ochronie danych osobowych względem danych osobowych ujawnionych w CEIDG znajduje również zastosowanie w zakresie uprawnień kontrolnych GIODO oraz inspektorów działających w oparciu o jej regulacje. W przypadku stwierdzenia naruszenia przepisów o ochronie danych osobowych przez podmiot przetwarzający dane podlegające ujawnieniu w Centralnej Ewidencji (a więc także i sam podmiot ją prowadzący) GIODO z urzędu lub na wniosek osoby zainteresowanej w drodze decyzji administracyjnej nakazuje przywrócenie stanu zgodnego z prawem. W wypadku stwierdzenia, że działanie lub zaniechanie kierownika jednostki organizacyjnej, jej pracownika lub innej osoby fizycznej będącej administratorem przedmiotowych danych wyczerpuje znamiona przestępstwa $\mathrm{z}$ art. 49-54a u.o.d.o., Generalny Inspektor kieruje do organów ścigania zawiadomienie o podejrzeniu popełnienia przestępstwa, dołączając zebrane przez siebie dowody. Postępowanie o podjęcie działań przez GIODO w przedmiocie ochrony danych podlegających ujawnieniu w CEIDG prowadzone jest według przepisów k.p.a. ${ }^{37}$ Przedsiębiorca, którego dane ujawniono w Centralnej Ewidencji, nie godząc się z decyzją Generalnego Inspektora, uprawniony jest do wystąpienia z wnioskiem o ponowne rozpatrzenie sprawy, a wówczas wydana decyzja jest zaskarżalna do sądu administracyjnego.

Odnosząc się do niepełnego stosowania przepisów u.o.d.o. względem danych ujawnianych w CEIDG należy zauważyć, że nawet bez wskazania z art. 39b u.s.d.g., niejako z natury rzeczy część z nich nie mogłaby znaleźć zastosowania do tych informacji. Przepisy takie zawiera art. 27 u.o.d.o. odnoszący się do szcze-

36 P. Barta, P. Litwiński, Ustawa o ochronie danych osobowych. Komentarz, Warszawa 2016, s. $82-83$.

37 Ustawa z dnia 14 czerwca 1960 r. Kodeks postępowania administracyjnego, tekst jedn. Dz.U. z 2017 r. poz. 1257 z późn. zm. 
gólnie wrażliwych danych osobowych, których zbierania nie przewiduje regulacja normująca funkcjonowanie Centralnej Ewidencji.

Wprowadzony nowelą z dnia 25 września 2015 r. stan prawny należy ocenić pozytywnie. Brak zastrzeżenia analogicznego do art. 7 a ust 2 u.p.d.g. wyłączenia spod ochrony u.o.d.o. danych przedsiębiorców wpisanych do CEIDG utrudniał prowadzenie działalności gospodarczej przez podmioty gromadzące ich dane, na których ciążyły liczne obowiązki, w tym zwłaszcza rozbudowane obowiązki informacyjne. W stanie prawnym sprzed nowelizacji występował daleko idący dualizm $\mathrm{w}$ zakresie traktowania danych osób uczestniczących w profesjonalnym obrocie - inne przepisy dotyczyły przetwarzania i gromadzenia danych osób prawnych, a inne danych kontrahentów prowadzących jednoosobową działalność gospodarczą ${ }^{38}$. Uzasadnione wątpliwości wzbudzało tak restrykcyjne podejście do danych ujawnianych $w$ jawnym rejestrze, jakim jest $\mathrm{CEIDG}^{39}$. Obecne uregulowanie częściowo przywraca stan sprzed 1 stycznia 2012 r., jednak zakres ochrony u.o.d.o. względem danych przedsiębiorców ujawnionych w CEIDG ograniczono do części jej uregulowań, znacząco ułatwiając przetwarzanie i gromadzenie danych przedsiębiorcy objętych jawnym dostępem, przy jednoczesnym zachowaniu zasadniczych funkcji ochronnych ustawy względem osób fizycznych prowadzących jednoosobowo działalność gospodarczą.

\section{OCHRONA DANYCH OSOBOWYCH UJAWNIANYCH W KRAJOWYM REJESTRZE SĄDOWYM}

Zgodnie z art. 6 ust. 1 u.o.d.o. ochrona danych osobowych obejmuje dane osób fizycznych, nie znajdując zastosowania do informacji o innych podmiotach prawa, takich jak osoby prawne i jednostki organizacyjne nieposiadające osobowości prawnej (spółki osobowe, oddziały przedsiębiorstw), nieformalne grupy, organy administracji państwowej etc. Ochrona ta nie będzie dotyczyła zatem danych niektórych podmiotów wpisanych do Krajowego Rejestru Sądowego. Składa się on z rejestru przedsiębiorców, rejestru dłużników niewypłacalnych i rejestru stowarzyszeń, innych organizacji społecznych i zawodowych, fundacji oraz samodzielnych publicznych zakładów opieki zdrowotnej (art. 1 ust. 2 u.k.r.s.) ${ }^{40}$. Niewątpliwie część danych zawartych w rejestrze dłużników niewypłacalnych jest

38 A. Kobylańska, P. Bukiel, Wizytówka wizytówce nierówna, „Rzeczpospolita” nr 10459 z 1 czerwca 2016 r., s. C-008.

39 Pojawiały się wręcz wskazania co do absurdalności takiego stanu rzeczy. Zob. D. Wociór, Dane z centralnej ewidencji znowu jawne, ,Rzeczpospolita” nr 10442 z 11 maja 2016 r., s. C-008.

40 Zgodnie z art. 1 ust. 2 u.k.r.s. rejestr ten wchodzi w skład systemu integracji rejestrów, o którym mowa w art. 22 Dyrektywy Parlamentu Europejskiego i Rady (UE) 2017/1132 z dnia 14 czerwca 2017 r. w sprawie niektórych aspektów prawa spółek, Dz. Urz. UE L 169 z 30 czerwca $2017 \mathrm{r}$. 
objęta ochroną u.o.d.o, gdyż figurują w nim m.in. dane osób fizycznych, które prowadziły działalność gospodarczą, wspólników spółek ponoszących odpowiedzialność całym swoim majątkiem za zobowiązania spółki (z wyłączeniem komandytariuszy), jeżeli ogłoszono upadłość spółki (względnie do tego nie doszło z uwagi na niewystarczający do tego stan jej majątku). W myśl art. 57 ust. 1 pkt 1 i 2 u.k.r.s. w przypadku osób fizycznych w rejestrze dłużników niewypłacalnych zamieszcza się ich nazwiska i imiona oraz numery PESEL, a nadto podstawę wpisu (np. poprzez wskazanie orzeczenia ze sprawy upadłościowej lub postępowania o wyjawienie majątku). Dane te zawierają informacje szczególnie istotne dla jednostki, wykazując ich złą sytuację finansową (niewypłacalność). Ujawniane są w rejestrze celem realizacji jego funkcji, jaką jest informowanie o zaistnieniu przyczyn kwalifikujących dłużnika jako podmiotu niewypłacalnego (funkcja informacyjna i ewidencyjna rejestru). Wpisy w rejestrze dłużników niewypłacalnych odmiennie aniżeli większość wpisów w rejestrze przedsiębiorców nie podlegają obowiązkowi ogłoszenia w Monitorze Sądowym i Gospodarczym (art. 58 u.k.r.s.) ${ }^{41}$. Na podstawie jej art. 2 ust. 1 dane te podlegają ochronie u.o.d.o.

Ochrona u.o.d.o. rozciąga się także na część danych wpisanych do pozostałych rejestrów KRS. W rejestrze stowarzyszeń, innych organizacji społecznych i zawodowych, fundacji oraz samodzielnych publicznych zakładów opieki zdrowotnej przy rejestracji stowarzyszenia, związku zawodowego, organizacji pracodawców i innych organizacji społecznych i zawodowych wpisuje się osoby wchodzące w skład komitetu założycielskiego, chyba że został powołany organ reprezentacji (art. 52 ust. 1 u.k.r.s.), a przy rejestracji samodzielnych publicznych zakładów opieki zdrowotnej oznaczenie podmiotu tworzącego, w rozumieniu przepisów o działalności leczniczej, oraz nazwisko i imiona kierownika samodzielnego publicznego zakładu opieki zdrowotnej i jego kwalifikacje oraz skład rady społecznej, jeżeli jest powołana (art. 53 u.k.r.s.).

Zakres podmiotów objętych obowiązkiem wpisu do rejestru przedsiębiorców określa art. 36 u.k.r.s., stanowiąc, że rejestr ten dotyczy m.in.: spółek jawnych, europejskich zgrupowań interesów gospodarczych, spółek partnerskich, spółek komandytowych, spółek komandytowo-akcyjnych, spółek z ograniczoną odpowiedzialnością, spółek akcyjnych, spółek europejskich, spółdzielni, spółdzielni europejskich, przedsiębiorstw państwowych, instytutów badawczych, towarzystw ubezpieczeń wzajemnych oraz wzajemnej reasekuracji, instytucji gospodarki budżetowej. Dane dotyczące poszczególnych przedsiębiorców wpisanych do tego rejestru umieszcza się pod numerem przeznaczonym dla danego podmiotu w sześciu działach tego rejestru (art. 37 u.k.r.s.). Wśród danych podlegających ujawnie-

${ }^{41}$ Nie należy jednak łączyć tej okoliczności z wolą ograniczenia rozpowszechnienia informacji w nich zawartych. Ma ona na celu uniknięcie ogłaszania w tym publikatorze treści o niewielkiej doniosłości dla obrotu gospodarczego oraz zmniejszenie kosztów postępowania o wpis do przedmiotowego rejestru. Tak Ł. Zamojski, Ustawa o Krajowym Rejestrze Sadowym. Komentarz, Warszawa 2009, s. 349. 
niu w KRS znajdują się takie informacje, jak m.in. nazwa lub firma, pod którą działa dany podmiot, jego siedziba i adres, numer NIP, adres strony internetowej $i$ adres poczty elektronicznej, (odnośnie do większości wspólników spółek osobowych) informacje o pozostawaniu w związku małżeńskim i o małżeńskim ustroju majątkowym oraz o ewentualnych ograniczeniach zdolności prawnej, przedmiot wkładu każdego komandytariusza z zaznaczeniem, w jakiej części został wniesiony; ponadto: wskazanie wspólników uprawnionych do reprezentowania spółki, wzmianki o złożeniu sprawozdań z działalności, oznaczenie wierzyciela podmiotu oraz jego wierzytelność, jeżeli posiada tytuł wykonawczy wystawiony przeciwko podmiotowi i nie został zaspokojony w ciągu 30 dni od daty wezwania do spełnienia świadczenia. W przypadku przedsiębiorstwa zagranicznego ujawnia się nazwisko i imiona osoby fizycznej lub określenie osoby prawnej, która uzyskała zezwolenie na prowadzenie tego przedsiębiorstwa na terytorium Rzeczypospolitej Polskiej, wraz z jej miejscem zamieszkania (siedzibą) i adresem ${ }^{42}$. Przytoczone przykłady wskazują, że wśród danych podlegających wpisom do poszczególnych działów rejestru znajdują się informacje pozwalające na identyfikację nie tylko danego przedsiębiorcy (przedsiębiorstwa w ujęciu przedmiotowym), lecz także funkcjonujących w jego ramach podmiotów, np. wspólników będących osobami fizycznymi. Omawiana ustawa wprowadza dostęp do Centralnej Informacji Krajowego Rejestru Sądowego, prowadzonej w formie oddziałów przy właściwych sądach rejestrowych ${ }^{43}$. Do jej zadań należy prowadzenie zbioru informacji Rejestru oraz elektronicznego katalogu dokumentów spółek, obejmującego określone dokumenty dotyczące spółek z ograniczoną odpowiedzialnością, spółek akcyjnych, spółek komandytowo-akcyjnych i spółek europejskich, m.in. ich akty założycielskie, umowy oraz statuty, jeżeli są oddzielnymi aktami, uchwały o powołaniu i odwołaniu członków organów spółek (art. 8a u.k.r.s.). Nie tylko zatem dane ujawnione w rejestrze KRS, lecz i poszczególne akty złożone do zbioru dokumentów zawierają informacje o osobach fizycznych (ewentualnie osobach prawnych, a także reprezentowanych przez określone osoby fizyczne) działających w imieniu osób prawnych lub jednostek organizacyjnych nieposiadających osobowości prawnej, którym ustawa przyznaje zdolność prawną, czy też o osobach zawiązujących je i wnoszących do nich wskazany kapitał (wspólnicy). Należy przychylić się do wyrażonego w doktrynie poglądu, wedle którego wyprowadzane a contrario z treści z art. 6 ust. 1 u.o.d.o. wyłączenie ochrony danych względem osób prawnych nie ma zastosowania do osób fizycznych działających w imieniu i na rzecz osób prawnych, jednostek organizacyjnych nieposiadających osobowości prawnej (w tym i takich, które posiadają przyznaną ustawowo zdolność prawną — spółek

${ }^{42}$ Zakres i szczegółowy tryb dokonywania przez przedsiębiorców zgłoszeń do Rejestru określa Rozporządzenie Ministra Sprawiedliwości z dnia 17 listopada 2014 r. w sprawie szczegółowego sposobu prowadzenia rejestrów wchodzących w skład Krajowego Rejestru Sądowego oraz szczegółowej treści wpisów w tych rejestrach, Dz.U. poz. 1667 z późn. zm.; dalej jako „rozporządzenie KRS”.

${ }^{43}$ Utworzonej przez Ministra Sprawiedliwości na podstawie delegacji z art. 4 ust. 1 u.k.r.s. 
osobowych, jak i jej pozbawionych — oddziałów), organów administracji, sądów itd. i dane te podlegają ochronie ustawy o ochronie danych osobowych. Przedmiotowe dane dotyczą bowiem osób fizycznych działających jedynie w ramach podmiotu podlegającego wpisowi do rejestru i tylko w kontekście tej działalności ich dane ujawniane są w rejestrze. W ich wypadku kwalifikatorem decydującym o objęciu ochroną u.o.d.o. jest możliwość identyfikacji danej osoby na warunkach wskazanych w art. 6 tej ustawy ${ }^{44}$. Prezentowane stanowisko potwierdza treść uzasadnienia wyroku NSA z dnia 24 stycznia $2013 \mathrm{r} .{ }^{45}$ Rozstrzygał on skargę spółki zajmującej się działalnością w zakresie tworzenia oprogramowania, doradztwa w zakresie prowadzenia działalności gospodarczej i zarządzania oraz działalnością związaną z bazami danych. Spółka ta zaskarżyła wyrok WSA w Warszawie podtrzymujący decyzję GIODO nakazującą jej wykonanie wielu wynikających z u.o.d.o. obowiązków związanych z gromadzeniem, przetwarzaniem i udostępnianiem przez Internet danych osób fizycznych pochodzących ze źródeł powszechnie dostępnych (Monitor Sądowy i Gospodarczy), a ujawnionych w rejestrze przedsiębiorców KRS - imion, nazwisk, numeru PESEL, pełnionych funkcji, dat urodzenia ${ }^{46}$. Naczelny Sąd Administracyjny jednoznacznie stwierdził, że dane dotyczące osób fizycznych wpisane do KRS są danymi osobowymi, a zasady ich przetwarzania, jak zbieranie, przekazywanie, utrwalanie, udostępnianie i zmienianie, reguluje u.k.r.s. Ustawa ta w sposób ścisły wskazuje zakres wpisanych do Rejestru danych osobowych dotyczących osób fizycznych, ograniczając je do nazwiska, imienia oraz identyfikatora nadanego w systemie ewidencji ludności (numer PESEL). Sąd wskazał, że art. 25 u.o.d.o. nakłada na administratora danych zbieranych w taki sposób, w jaki czyniła to przedmiotowa spółka, powinność powiadomienia osoby, której dane osobowe dotyczą, o adresie siedziby i pełnej nazwie lub imieniu i nazwisku bądź (gdy administratorem jest osoba fizyczna) miejscu zamieszkania, celu i zakresie zbierania danych oraz odbiorcach, źródle, prawie dostępu do treści swoich danych oraz ich poprawiania i o uprawnieniach wynikających z art. 32 ust. 1 pkt 7 i 8 u.o.d.o. Równocześnie zastrzeżono, że obowiązki te są zniesione, jeżeli przepis innej ustawy przewiduje lub dopuszcza zbieranie danych osobowych bez wiedzy osoby, której dane dotyczą (art. 25 ust. 1 pkt 1 u.o.d.o.). Skarżąca spółka, powołując się na treść art. 8 u.k.r.s. statuującego zasadę jawności danych zawartych w Rejestrze, tj. prawo dostępu do danych zawartych w nich za pośrednictwem Centralnej Informacji Krajowego Rejestru Sądowego oraz wyrażony w art. 13 u.k.r.s. obowiązek upublicznienia wpisów przez ogłoszenie ich w Monitorze Sądowym i Gospodarczym, wskazywała, że zawarta w nich

44 Tak m.in. A. Krasuski, Outsourcing danych osobowych $w$ działalności przedsiębiorstw, Warszawa 2010, s. 43-44; A. Krasuski, D. Skolimowska, Dane osobowe w przedsiębiorstwie, Warszawa 2007, s. 39-40.

45 Wyrok NSA z dnia 24 stycznia 2013 r., I OSK 1827/11, Lex nr 1554654.

46 Wyrok WSA w Warszawie z dnia 2 czerwca 2011 r., II SA/Wa 720/11, http://orzeczenia. nsa.gov.pl/doc/EF84A3A48E (dostęp: 20.05.2018). 
treść normatywna odpowiada przesłankom wyłączającym obowiązek informacyjny z u.o.d.o. Naczelny Sąd Administracyjny zważył, że zakres danych osobowych ujawnianych w KRS odpowiada celowi, w jakim rejestr został utworzony, a którym jest zapewnienie jawności i pewności obrotu gospodarczego. W zakresie danych dotyczących reprezentacji podmiotów gospodarczych zawiera on bowiem oznaczenie organu uprawnionego do reprezentowania podmiotu oraz osób wchodzących w jego skład ze wskazaniem sposobu reprezentacji (art. 39 pkt 1 u.k.r.s.). W ocenie Sądu ze wskazanym celem nie można jednak utożsamiać celu, dla którego spółka skarżąca przetwarzała dane osobowe, tj. działalności komercyjnej polegającej na zbieraniu, utrwalaniu i udostępnianiu danych. Jawność i powszechna dostępność danych z rejestru KRS oraz cel, jaki realizuje tą drogą ustawodawca, determinuje rodzaj i zakres przetwarzania danych osobowych osób fizycznych. Ustawodawca dopuszcza możliwość przetwarzania danych obejmujących imię, nazwisko, pełnioną w podmiotach funkcję oraz numer PESEL, tj. dane ściśle powiązane ze sferą obrotu gospodarczego. Rejestr nie ujawnia przy tym bardziej szczegółowych danych osób fizycznych (np. miejsca zamieszkania), co oznacza, że w zakresie niezwiązanym bezpośrednio ze sferą obrotu u.k.r.s. chroni prywatność osób w nim figurujących ${ }^{47}$. Sytuacja ta pozostaje zgodna z wynikającym z art. 51 Konstytucji Rzeczypospolitej Polskiej prawem jednostki do zachowania $\mathrm{w}$ tajemnicy informacji dotyczącej własnej osoby i zakazem innego niż ustawowe zobowiązania jednostki do ujawnienia informacji jej dotyczących i skorelowanym z nim zakazem pozyskiwania, gromadzenia i udostępniania przez władze publiczne innych informacji o obywatelach niż niezbędne w demokratycznym państwie prawnym. Przetwarzanie danych osobowych osób fizycznych sprawujących funkcje organów osób prawnych czy też wspólników spółek osobowych (względnie także takich osób, jak członkowie zarządu spółki partnerskiej, prokurenci spółki) może być uznane za bezprawne, gdy nie odbywa się ono w celu i zakresie niezbędnym do prawidłowego ich zidentyfikowania jako pełniących wskazane funkcje ${ }^{48}$. Aprobując to stanowisko, należy podkreślić, że przywołane z art. 43 ust. 1 pkt 9 u.o.d.o. wyłączenie obowiązku rejestracji zbioru danych osobowych zawartych w jawnym rejestrze, np. każdym z trzech rejestrów wchodzących w skład KRS,

47 Spostrzeżenie NSA nie jest jednak pełne; w myśl art. 38 pkt 4a u.k.r.s. w dziale 1 rejestru przedsiębiorców w przypadku europejskiego zgrupowania interesów gospodarczych zamieszcza się m.in. imię i nazwisko oraz miejsce zamieszkania lub oznaczenie nazwy, firmy, formy prawnej, siedziby statutowej oraz numeru i miejsca rejestracji członków europejskiego zgrupowania interesów gospodarczych, a w myśl art. 38 pkt 12 u.k.r.s., w przypadku przedsiębiorstwa zagranicznego ujawnia się w tym dziale nazwisko i imiona osoby fizycznej lub określenie osoby prawnej, która uzyskała zezwolenie na prowadzenie tego przedsiębiorstwa na terytorium Rzeczypospolitej Polskiej, wraz z miejscem zamieszkania (siedzibą) $\mathrm{i}$ adresem tej osoby.

48 P. Barta, P. Litwiński, op. cit., s. 80-81. Autorzy przywołują wyrok Sądu Apelacyjnego w Gdańsku z dnia 15 marca 1996 r. (I ACR 33/96, OSA 1996, Nr 7-8, poz. 31), wskazującego konieczność uwzględnienia celu wykorzystywania danych osobowych i braku bezprawności przy przetwarzaniu ich zgodnie z regułami społecznymi. 
dotyczy jedynie wypadku, gdy są one upublicznione przez administratora, który te dane zgromadził (w omawianym przypadku — wydziały sądów rejonowych). W sytuacji, gdy dane te są wtórnie gromadzone przez inny podmiot, ciąży na nim obowiązek ich rejestracji u GIODO ${ }^{49}$.

\section{PODSUMOWANIE}

Należy podkreślić, że ze względu na znaczną obszerność tematu przedstawione uwagi traktują jedynie o danych ujawnianych w CEIDG oraz w KRS ${ }^{50}$. Dane te w obecnym modelu podlegają ochronie ustawy o ochronie danych osobowych jedynie w ograniczonym zakresie. W przypadku przedsiębiorców ujawnionych w CEIDG jest ona stosowana w zakresie obowiązku zabezpieczenia zgromadzonych danych, uprawnień kontrolnych GIODO i przepisów karnych związanych z naruszeniami. Wyłączony jest imperatyw dochowania przesłanek przetwarzania danych i obowiązków informacyjnych. Żadne z przepisów u.o.d.o. nie znajdują zastosowania względem danych osób prawnych, jednostek nieposiadających osobowości prawnej, którym ustawa przyznaje zdolność prawną (w tym osobowych spółek handlowych) i innych podmiotów niebędących osobami fizycznymi. Dane ujawnione w KRS nie podlegają zatem ochronie ustawy, o ile nie dotyczą osób fizycznych. Dane takich osób będących wspólnikami spółki, członkami organów czy też dane osób fizycznych wpisanych na listę dłużników niewypłacalnych chronione są postanowieniami u.o.d.o., gdy są wykorzystywane w celu innym, niż ich identyfikacja jako pełniących wskazane funkcje bądź jako osób figurujących w rejestrze dłużników niewypłacalnych. Niezależnie od uregulowań u.o.d.o. dane traktujące o przedsiębiorcach — osobach prawnych i jednostkach organizacyjnych nieposiadających osobowości prawnej, którym ustawa przyznaje zdolność prawną, są chronione przez postanowienia kodeksu cywilnego o ochronie dóbr osobistych osób prawnych, jak również (bezpośrednio) przez przepisy niektórych ustaw szczegółowych, np. ustawy o statystyce publicznej ${ }^{51}$.

49 P. Kowalik, D. Wociór, Zgłaszanie zbiorów danych osobowych do rejestracji do GIODO, [w:] A. Balicki et al., Ochrona danych osobowych w sektorze publicznym z uwzględnieniem ogólnego rozporzadzenia unijnego, Warszawa 2016, s. 67.

50 Oprócz nich funkcjonuje także wiele innych rejestrów zawierających informacje o przedsiębiorcach (np. obowiązkowe rejestry niezbędne do prowadzenia regulowanej działalności gospodarczej, takie jak Rejestr przedsiębiorców telekomunikacyjnych Urzędu Komunikacji Elektronicznej), które, o ile przepis innej ustawy tego nie wyłącza, mogą być zbierane i przetwarzane jedynie za wiedzą osób fizycznych, których dotyczą.

51 Ustawa z dnia 29 czerwca 1995 r. o statystyce publicznej (tekst jedn. Dz.U. z 2016 r. poz. 1068 z późn. zm.), tak J. Barta, P. Fajgielski, R. Markiewicz, op. cit., s. 305. O przetwarzaniu, udostępnianiu i przechowywaniu danych osobowych do celów statystycznych ustawa ta traktuje w art. 35a-39. 


\title{
REGISTERS OF ENTREPRENEURS AND PROTECTION OF PERSONAL DATA
}

\begin{abstract}
Summary
Currently, in Polish law there are different regulations regarding the protection of personal data of entrepreneurs depending on whether they are natural persons disclosed in the Central Register and Information on Business Activity or are other entities (capital companies, foundations, partnerships etc.), disclosed in the National Court Register. Explicit data provided by the Central Registry are generally subject to the Act of 29 August 1997 on the protection of personal data. The entities that process data contained therein must perform only certain duties. None of the provisions of the Act are applied to entrepreneurs disclosed in the National Court Register. These data are not protected by the Act if they do not apply to natural persons. The personal data of natural persons disclosed in this Register are covered by the protection of the Act, if they are used for purposes other than their identification as performing functions in commercial companies or as persons appearing in the register of insolvent debtors.
\end{abstract}

Keywords: protection of personal data, KRS, CEIDG, business registers, Central Register and Information on Business Activity, National Court Register

\section{BIBLIOGRAFIA}

\section{LITERATURA PRZEDMIOTU}

Barta J., Fajgielski P., Markiewicz R., Ochrona danych osobowych. Komentarz, Warszawa 2015.

Barta J., Markiewicz R., Ochrona danych osobowych. Komentarz, Zakamycze 2001.

Barta P., Litwiński P., Ustawa o ochronie danych osobowych. Komentarz, Warszawa 2016.

Drozd A., Ustawa o ochronie danych osobowych. Komentarz. Wzory pism i przepisy, Warszawa 2006.

Drozd A., Ustawa o ochronie danych osobowych. Komentarz. Wzory pism i przepisy, Warszawa 2007.

Jackowski M., Glosa do wyroku z 28.XI.2002 r., II S.A. 3389/01, „Państwo i Prawo” 2004, nr 10, s. $126-131$.

Kobylańska A., Bukiel P., Wizytówka wizytówce nierówna, „Rzeczpospolita” nr 10459 z 1 czerwca 2016 r., s. C-008.

Konarski X., Komentarz do ustawy o świadczeniu usług droga elektroniczna, Warszawa 2004.

Kowalik P., Wociór D., Zgłaszanie zbiorów danych osobowych do rejestracji do GIODO, [w:] A. Balicki et al., Ochrona danych osobowych w sektorze publicznym z uwzględnieniem ogólnego rozporzadzenia unijnego, Warszawa 2016, s. 53-69.

Krasuski A., Outsourcing danych osobowych w działalności przedsiębiorstw, Warszawa 2010.

Krasuski A., Skolimowska D., Dane osobowe w przedsiębiorstwie, Warszawa 2007.

Mednis A., Ustawa o ochronie danych osobowych. Komentarz, Warszawa 1999.

Mednis A., Ustawa o ochronie danych osobowych w orzecznictwie sadowym - konsekwencje dla praktyki gospodarczej, [w:] Ochrona danych osobowych. Aktualne problemy i nowe wyzwania, red. G. Sibiga, X. Konarski, Warszawa 2007, s. 223-254.

Sibiga G., Postępowanie w sprawach ochrony danych osobowych, Warszawa 2003.

Szpor G., Publicznoprawna ochrona danych osobowych, „Przegląd Ustawodawstwa Gospodarczego" 1999 , nr 12, s. 2-13. 
Wiewiórkowski W.R., Nowoczesne ramy ochrony danych osobowych w Unii Europejskiej, „Monitor Prawniczy" 2012, nr 7 (dodatek specjalny), s. 2-9.

Wociór D., Dane z centralnej ewidencji znowu jawne, „Rzeczpospolita” nr 10442 z 11 maja 2016 r., s. C-008.

Zamojski Ł., Ustawa o Krajowym Rejestrze Sądowym. Komentarz, Warszawa 2009.

Zielińska M., Nazwa spółki cywilnej jako dobro osobiste, „Prawo Spółek” 1998, nr 11, s. 7-11.

\section{AKTY PRAWNE}

Dekret Naczelnika Państwa z dnia 7 lutego 1919 r. o rejestrze handlowym, Dziennik Praw Państwa Polskiego nr 14 poz. 164.

Dyrektywa 95/46/WE Parlamentu Europejskiego i Rady z dnia 24 października 1995 r. w sprawie ochrony osób fizycznych w zakresie przetwarzania danych osobowych i swobodnego przepływu tych danych, Dz.U. L 281 z 23 listopada 1995 r.

Dyrektywa Parlamentu Europejskiego i Rady (UE) 2017/1132 z dnia 14 czerwca 2017 r. w sprawie niektórych aspektów prawa spółek, Dz.Urz. UE L 169 z 30 czerwca 2017 r.

Konwencja 108 Rady Europy z dnia 28 stycznia 1981 r. dotyczącą ochrony osób w związku z automatycznym przetwarzaniem danych osobowych, Dz.U. z 2003 r. Nr 3, poz. 25.

Rozporządzenie Ministra Sprawiedliwości z dnia 17 listopada 2014 r. w sprawie szczegółowego sposobu prowadzenia rejestrów wchodzących w skład Krajowego Rejestru Sądowego oraz szczegółowej treści wpisów w tych rejestrach, Dz.U. poz. 1667 z późn. zm.

Rozporządzenie Parlamentu Europejskiego i Rady (UE) 2016/679 z dnia 27 kwietnia 2016 r. w sprawie ochrony osób fizycznych w związku z przetwarzaniem danych osobowych i w sprawie swobodnego przepływu takich danych oraz uchylenia dyrektywy 95/46/WE, Dz. UE L 119 z 4 maja 2016.

Ustawa z dnia 14 czerwca 1960 r. Kodeks postępowania administracyjnego, tekst jedn. Dz.U. z 2017 r. poz. 1257 z późn. zm.

Ustawa z dnia 29 czerwca 1995 r. o statystyce publicznej, Dz.U. z 2016 r. poz. 1068 z późn. zm.

Ustawa z dnia 20 sierpnia 1997 r. o Krajowym Rejestrze Sądowym, tekst jedn. Dz.U. z 2017 r. poz. 700 z późn. zm. Ustawa z dnia 29 sierpnia 1997 r. o ochronie danych osobowych, tekst jedn. Dz.U. z 2016 r. poz. 922 z późn. zm. Ustawa z dnia 19 listopada 1999 r. Prawo działalności gospodarczej, Dz.U. z 1999 r. Nr 101, poz. 1178 z późn. zm. Ustawa z dnia 14 listopada 2003 r. o zmianie ustawy - Prawo działalności gospodarczej oraz niektórych innych ustaw, Dz.U. Nr 217, poz. 2125.

Ustawa z dnia 2 lipca 2004 r. o swobodzie działalności gospodarczej, tekst jedn. Dz.U. z 2017 r. poz. 2168 z późn. zm. Ustawa z dnia 25 września 2015 r. o zmianie ustawy o swobodzie działalności gospodarczej oraz niektórych innych ustaw, Dz.U. poz. 1893.

\section{ORZECZNICTWO}

Wyrok SN z dnia 14 lipca 1999 r., II CKN 351/98, OSNC 2000, Nr 2, poz. 36.

Wyrok NSA z dnia 28 listopada 2002 r., II S.A. 3389/01, publ. Centralna Baza Orzeczeń Sądów Administracyjnych, http://orzeczenia.nsa.gov.pl/doc/C02DDC2452.

Wyrok NSA z dnia 15 marca 2010 r., I OSK 756/09, Lex nr 590310.

Wyrok NSA z dnia 24 stycznia 2013 r., I OSK 1827/11, Lex nr 1554654.

Wyrok SA w Gdańsku z dnia 15 marca 1996 r. I ACR 33/96, OSA 1996, Nr 7-8, poz. 31.

Wyrok WSA w Warszawie z dnia 2 czerwca 2011 r., II SA/Wa 720/11, http://orzeczenia.nsa.gov.p1/ doc/EF84A3A48E. 


\section{INNE ŹRÓDŁA}

Decyzja GIODO nr GI-DEC-DS-279/05 z dnia 1 września 2005 r., http://www.giodo.gov.pl/311/ id_art/1508/j/p1/'.

Projekt ustawy o ochronie danych osobowych z dnia 8 lutego 2018 r., https://www.gov.pl/cyfryzacja/ projekt-ustawy-o-ochronie-danych-osobowych-skierowany-na-komitet-do-spraweuropejskich -rady-ministrow. 